\title{
THE EFFECT OF DIFFERENT SOWING TIMES ON FRESH EAR YIELD AND YIELD COMPONENTS IN SWEET CORN (ZEA MAYS L. SACCHARATA STURT.) VARIETIES
}

\author{
Sevda KILINÇ ${ }^{1, *}$, Şehmus ATAKUL ${ }^{1}$, Şerif KAHRAMAN ${ }^{1}$, \\ Hüsnü AKTAŞ ${ }^{2}$, İrfan ERDEMCİ ${ }^{1}$, Özlem AVŞAR ${ }^{1}$, İsmail GÜL ${ }^{3}$ \\ `E-mail: sevda.kilinc@tarimorman.gov.tr; ozlem.avsar@tarimorman.gov.tr
}

Received: June 29, 2021. Revised: Aug. 19, 2021 Accepted: Aug. 25, 2021. Published online: 17 Sep. 2021

\begin{abstract}
This study was carried out to investigate the effects of different sowing times on duration of tasselling, plant height, first ear height, ear length, ear diameter, number of ears per plant, fresh ear yield with husk, fresh ear yield unhusked, and marketable number of ears of different sweet corn (Zea mays L. saccharata Sturt.) varieties in Diyarbakir between the years of 2010-2012. The trial was conducted as split plots in randomised complete blocks with three replications. The main plots were sowing times, and the sub-plots were varieties. The trials were carried out at eight different sowing times (1 April, 15 April, 1 May, 15 May, 1 June, 15 June, 1 July and 15 July) with 'Merit', 'Jubilee', 'Lumina', 'Vega' and 'Sakarya' composite sweet corn varieties. From the variance analysis of the three-year combined average, the duration of tasselling, plant height, first ear height, ear length, ear diameter, number of ears per plant, fresh husked ear yield, fresh unhusked ear yield and marketable ear number were statistically significant for
\end{abstract}

sowing times and varieties. According to the sowing time $\times$ variety interaction, except ears per plant and first ear height values, all other traits were significant. The fresh husked and unhusked ear yields varied between 8541.7-19396.8 $\mathrm{kg} \mathrm{ha}^{-1}$ and 5065.0-13485.7 $\mathrm{kg} \mathrm{ha}^{-1}$, respectively. The highest fresh husked and fresh unhusked ear yields were obtained from the 15 April sowing time of 'Vega' variety. The results state that optimal sowing dates for different varieties of sweet corn could be from 1 April to 1 May, and the most suitable variety to be planted is 'Vega' in Diyarbakır conditions.

Keywords: sweet corn; sowing time; variety; yield and yield components.

\section{INTRODUCTION}

Corn (Zea mays L.), which is grown in large areas in Turkey, ranks second after wheat for production amount among grains (Tuik, 2020). Corn varieties are categorised in seven

\footnotetext{
1 GAP International Agricultural Research and Training Center, Diyarbakır, Turkey

2 Mardin Artuklu University, Vocatıonal Hıgher School of Kızltepe, Mardin, Turkey

${ }^{3}$ Kilis 7 Aralık University, Vocational School of Technical Sciences, Kilis, Turkey
} 


\section{Sevda KILINÇ ET AL.}

groups: dent corn, flint corn, popcorn, sweet corn, floury corn, pod corn and waxy corn varieties. Sweet corn (Zea mays L. saccharata Sturt.), which was first brought to our country in the 1930 s, is a corn sub-type whose consumption is increasing rapidly in the world and our country because of its nutritional content and its different uses as fresh, frozen and canned food (Öktem and Öktem, 2006). Sweet corn, which is similar to other corn types for plant growth and ear structure, contains a high amount of sugar in its endosperm during the milk stage. Since the largest embryo among the corn subspecies is found in sweet corn, it also has the highest fat and protein ratio. The nutritional value of sweet corn grains harvested during the milk stage is quite high. As the ears are consumed directly by boiling in water and roasting on a fire, the grains separated from the ears are used in the food industry by canning or freezing.

The consumption of canned foods and salad garnishes made plain or mixed with some other foods are becoming widespread with the increase in consumption of sweet corn that can be grown in areas where corn is cultivated in Turkey. Producers who turn to sweet corn cultivation know about its culture, and the increase in industrial facilities that will process freshly harvested sweet corn ears will bring sweet corn to a more important position. Fresh corn consumption in our country is mostly of dent corn and hard corn. Production and consumption may be expected to increase because of a shift in the consumption potential in favour of sweet corn. The introduction of sweet corn will contribute to the expansion of the food range consumed in our country, enable a balanced diet and provide producers with the opportunity of profitable and alternative products (Öktem and Öktem, 2006).

Leftover stalks and leaves of sweet corn that are consumed as fresh ears are good animal feeds. These plants can be fed directly to animals or used in making silage. Consumer preferences also stand out as a key factor in the marketing of sweet corn. The most critical features of the sweet corn to be grown for fresh ear consumption are large ears, kernel tip filling, row arrangement and kernel shape and size, among others. Grain yield in fresh ears is crucial for the industrial types of sweet corn grown for canning purposes.

The selection of suitable sowing and harvest time has great importance for achieving the true potential of sweet corn hybrids (Mehta et al., 2017). The last and first frost dates of a region and high temperatures during the pollination period are the principal factors limiting the sowing time. The yield of plants depends on the environment and cultivation techniques as well as their genetic potential (Ülger and Becker, 1989; Precheur et al., 2006). It is vital to determine the adaptation capabilities and planting times of high-yield sweet corn varieties suitable for the regions to increase sweet corn production. When and which varieties will be grown in a region depends on the 
ecological conditions of the region, the purpose of the product and consumer preferences (Sencar et al., 1999). For this reason, it is necessary to determine the appropriate sowing time, varieties and breeding purposes.

This study aims to determine the most suitable sweet corn planting time for Diyarbakır, Turkey, conditions and the potential high yield sweet corn varieties that respond to the producer and consumer demands for productivity.

\section{MATERIALS AND METHODS}

The research was conducted in the experimental area of the GAP International Agricultural Research and Training Centre during 2010-2012. The trial land where the research was conducted is flat, and organic matter content is low. Some physical and chemical analyses of the soil samples taken from the area where the experiment was carried out were performed in the GAP International Agricultural Research and Training Centre Soil Analysis Laboratory, and the analysis results are given in Table 1.

In Diyarbakır, Turkey, where the research was conducted, summers are hot, dry and long, while winters are cold and somewhat rainy. The average annual rainfall is $496 \mathrm{~mm}$ (Anonymous, 2012). Some climate data for long years (19752010) and 2010-2012 are given in Table 2.

In the experiment, five varieties of sweet corn ('Jubilee', 'Sakarya' Composite, 'Vega', 'Merit' and 'Lumina') were used as plant material and eight planting dates (1 April, 15 April, 1 May, 15 May, 1 June, 15 June, 1 July and 15 July) were chosen for the trial. Sweet corn is divided into four groups: standard (normal sugar content), super sweet (high sugar content), sugar-enhanced (increased sugar content) and synergistic (very uncommon and unknown), according to the amount of sugar content (Erdal and Pamukçu, 2005). The characteristics of the 'Jubilee', 'Lumina', 'Merit' and 'Vega' varieties, as well as the 'Sakarya' composite cultivar, are given in Table 3.

The trial was conducted as split plots in randomised complete blocks with three replications. Main plots were sowing times and sub-plots were varieties. Each plot was $5 \times 2.8 \mathrm{~m}$ and consisted of four rows. The distance between the rows was $70 \mathrm{~cm}$ and the inter-row spacing was $20 \mathrm{~cm}$. As a fertiliser, $300 \mathrm{~kg}$ pure nitrogen $(\mathrm{N})$ and $100 \mathrm{~kg}$ pure phosphorus $\left(\mathrm{P}_{2} \mathrm{O}_{5}\right)$ were given per hectare. Before planting, $100 \mathrm{~kg} \mathrm{ha}^{-1} \mathrm{~N}$ and $100 \mathrm{~kg} \mathrm{ha}^{-1} \mathrm{P}_{2} \mathrm{O}_{5}$ were applied in the form of compound fertiliser (20-20-0). The remaining $\mathrm{N}$ was implemented in the form of ammonium nitrate when the plants had 6-8 leaves (V6-V8). Except for this, routine maintenance procedures were applied in the trial. The seeds were sown at 5-6 cm depths. In both years, sufficient irrigation water was applied to all treatments. Two rows in the middle of the plots were harvested so that the harvest area was $7 \mathrm{~m}^{2}$, and all data were taken from the middle of two rows. All treatments were harvested during the milk stage. Harvest time was determined according to the "thumbnail test" method (Çetinkol, 1989).

Table 1 - Some physical and chemical properties of the trial area soils

\begin{tabular}{ccccccccc}
\hline $\begin{array}{c}\text { Depth } \\
(\mathbf{c m})\end{array}$ & Texture pH $\begin{array}{c}\text { Lime } \\
\left(\mathrm{CaCO}_{3}\right) \\
(\%)\end{array}$ & $\begin{array}{c}\text { Total } \\
\text { Salt } \\
(\%)\end{array}$ & Class & $\begin{array}{c}\text { Available } \\
\mathbf{P}_{2} \mathbf{O}_{5} \\
(\mathbf{k g} / \mathbf{h a})\end{array}$ & $\begin{array}{c}\text { Available } \\
\mathbf{K}_{2} \mathbf{O} \\
(\mathbf{k g} / \mathrm{ha})\end{array}$ & $\begin{array}{c}\text { Organic } \\
\text { Matter } \\
(\%)\end{array}$ \\
\hline $0-20$ & $\begin{array}{c}\text { Clay- } \\
\text { Loam }\end{array}$ & $\begin{array}{c}7 . \\
6\end{array}$ & 9.5 & 0.092 & Saltless & 1.43 & 124.17 & 0.78 \\
\hline
\end{tabular}


Sevda KILINÇ ET AL.

Table 2 - Monthly climate data during the growth period of sweet corn in 2010-2012 and long years in Diyarbakır

\begin{tabular}{|c|c|c|c|c|c|c|c|c|}
\hline $\begin{array}{l}\text { Meteorological } \\
\text { parameters }\end{array}$ & Years & April & May & June & July & Aug. & Sept. & Oct. \\
\hline \multirow{4}{*}{$\begin{array}{l}\text { Average } \\
\text { temperature }\left({ }^{\circ} \mathrm{C}\right)\end{array}$} & 2010 & 14.2 & 20.4 & 27.2 & 32.3 & 32.0 & 27.0 & 18.5 \\
\hline & 2011 & 13.0 & 17.7 & 25.5 & 31.4 & 30.7 & 25.0 & 18.1 \\
\hline & 2012 & 15.2 & 19.6 & 27.7 & 31.3 & 31.1 & 26.1 & 16.4 \\
\hline & L. Years* & 13.8 & 19.3 & 26.3 & 31.2 & 30.3 & 24.8 & 17.2 \\
\hline \multirow{4}{*}{$\begin{array}{l}\text { Average } \\
\text { maximum } \\
\text { temperature }\left({ }^{\circ} \mathrm{C}\right)\end{array}$} & 2010 & 22.0 & 28.1 & 35.8 & 40.3 & 40.3 & 35.5 & 27.1 \\
\hline & 2011 & 18.4 & 24.5 & 33.5 & 39.5 & 38.5 & 32.9 & 31.0 \\
\hline & 2012 & 22.6 & 27.1 & 35.7 & 38.6 & 38.6 & 34.4 & 24.0 \\
\hline & L. Years* & 20.2 & 26.5 & 33.7 & 38.4 & 38.1 & 33.2 & 25.2 \\
\hline \multirow{4}{*}{$\begin{array}{l}\text { Monthly average } \\
\text { rainfall ( } \mathrm{mm})\end{array}$} & 2010 & 22.4 & 31.6 & 11.2 & 0 & 0 & 0.4 & 62.4 \\
\hline & 2011 & 209.0 & 80.1 & 13.6 & 0.6 & 0 & 9.2 & 63.0 \\
\hline & 2012 & 26.2 & 41.0 & 7.0 & 1.6 & 0 & 1.8 & 11.8 \\
\hline & L. Years* & 68.7 & 41.3 & 7.9 & 0.5 & 0.4 & 4.1 & 34.7 \\
\hline \multirow{4}{*}{$\begin{array}{l}\text { Average relative } \\
\text { humidity }(\%)\end{array}$} & 2010 & 60.4 & 49.3 & 29.1 & 19.6 & 17.5 & 27.4 & 56.0 \\
\hline & 2011 & 75.7 & 67.6 & 38.0 & 22.5 & 21.7 & 30.2 & 41.6 \\
\hline & 2012 & 58.5 & 58.0 & 27.8 & 20.2 & 20.8 & 23.1 & 55.2 \\
\hline & L.Years & 63.0 & 56.0 & 31.0 & 27.0 & 28.0 & 32.0 & 48.0 \\
\hline
\end{tabular}

References: Diyarbakir meteorological directorate https://www.mgm.gov.tr/; *between 1975-2010 years

Table 3 - Sweet corn types used in the experiment and the institutions provided

\begin{tabular}{llll}
\hline $\begin{array}{l}\text { Variety } \\
\text { name }\end{array}$ & $\begin{array}{l}\text { Sugar } \\
\text { content }\end{array}$ & $\begin{array}{l}\text { Genetic } \\
\text { characteristics }\end{array}$ & Providing institution \\
\hline 'Jubilee' & standard & su gene & Monsanto Gida ve Tarim Tic. Ltd. Şti. \\
\hline $\begin{array}{l}\text { 'Sakarya' } \\
\text { composite }\end{array}$ & standard & su gene & Sakarya Tarimsal Araştirma Enstitüsü \\
\hline 'Vega' & super sweet & sh-2 gene & May Agro Tohumculuk San ve Tic.A.Ş. \\
\hline 'Merit' & standard & su gene & May Agro Tohumculuk San ve Tic. A. Ş. \\
\hline 'Lumina' & standard & su gene & Anadolu Tohum Üretim ve Paz. A.Ş. \\
\hline
\end{tabular}

In the study, the days of tasselling, plant height, the height of the first ear, number of ears per plant, ear length, ear diameter, fresh husked ear yield, fresh unhusked ear yield and marketable ear number features were investigated. Measurements of plant height, first ear height, ear length and ear diameter were taken from 10 randomly selected plants in the middle of two rows for each plot, while the number of ears per plant, fresh ear yield (husked and unhusked) and the marketable number of ears were taken from all plants in the middle of two rows of the plot. The measurements and observations of the characteristics examined in the study were made according to the methods of the Ministry of Agriculture and Forestry, Agricultural Values Measurement Trials Technical Instruction (Anonymous, 2019) and CIMMYT-IBPGR (Anonymous, 1991).

Data obtained in the study were evaluated on the computer using the JMP 5.1 statistical package. Analysis of variance (ANOVA) was obtained by combining years. Differences between sowing time and varieties means were 
identified with the Least Significant Difference (LSD) test.

\section{RESULTS AND DISCUSSION}

Average values and obtained findings of the properties examined are given in Tables 4-12.

\section{Days of tasselling}

The sowing time, variety and sowing time $\times$ variety interaction was statistically significant at the $p \leq 0.01$ probability level for tasselling time (Table 4). From Table 4, the average values for sowing times ranged between 51.6 days (1 June) and 77.3 days (1 April), the average values of the varieties ranged between 58.1 days ('Sakarya' composite) and 59.6 days ('Merit'), and the average values of interactions between sowing time and varieties varied between 50.7 days (15 June $\times$ 'Sakarya' composite) and 79.5 days ( 1 April $\times$ 'Merit').

For sowing times, the sowing time of 1 April formed had the highest tasselling time, while the sowing times of 1 June, 15 June and 1 July had the lowest tasselling times. Among varieties, 'Merit' had the highest tasselling time, while the 'Sakarya' Composite had the lowest. For sowing time $\times$ variety interactions, the 1 April $x$ 'Merit' interaction had the highest tasselling time, while the 15 June $\times$ 'Sakarya' composite interaction had the lowest. In the study, the number of days of tasselling time of varieties varied according to the sowing times. In this case, the varieties were affected differently from the sowing times, and the flowering varied depending on the temperature values. Sönmez (2013) reported that early flowering is important for pollen formation. Mehta et al. (2017) also emphasised that the planting time is essential in determining the flowering time. Our findings are in line with Cesurer (1995), Sencar et al. (1997), Lushsinger and Camilo (2008), Khan et al. (2009), Alan et al. (2011), Kara (2011), Khan et al. (2011) and Kula and Karadogan (2017).

\section{Plant height (cm)}

For plant height, the variety was significant at the level of 0.01 . The sowing time, and the sowing time $x$ variety interaction was significant at the level of 0.05 (Table 5).

From Table 5, the average values for sowing times for plant height ranged between $173.5 \mathrm{~cm}$ (1 April) and $193.6 \mathrm{~cm}$ (15 July). The average plant height values of the varieties ranged between $166.19 \mathrm{~cm}$ ('Vega') and $200.18 \mathrm{~cm}$ ('Sakarya' composite.), and average values for interactions between sowing time and varieties varied between $152.7 \mathrm{~cm}$ (1 April $\times$ 'Vega') and $207.8 \mathrm{~cm}$ (1 June $\times$ 'Sakarya' composite). For sowing times, the 1 May, 1 June and 15 July sowings had the tallest heights, while the 1 April sowing had the shortest plant heights. For the varieties, the 'Sakarya' composite had the tallest heights, while 'Vega' had the shortest. Meanwhile, the 'Merit' variety had the tallest plants for the 1 May and 15 July plantings, while the 'Sakarya' composite sown 1 May, 15 May, 1 June and 15 June and 'Vega' sown on 1 April had the shortest plants in the sowing time $\times$ variety interaction. 
Sevda KILINÇ ET AL.

Table 4 - Average days of tasselling values of some maize cultivars at different sowing times

\begin{tabular}{|c|c|c|c|c|c|c|}
\hline \multirow{2}{*}{$\begin{array}{l}\text { Sowing } \\
\text { time }\end{array}$} & \multicolumn{5}{|c|}{ Varieties } & \multirow{2}{*}{ Average } \\
\hline & 'Merit' & 'Lumina' & 'Jubilee' & 'Vega' & 'Sakarya' & \\
\hline 1 April & $79.5 \mathrm{a}$ & $76.5 \mathrm{c}$ & $77.7 \mathrm{~b}$ & $76.6 \mathrm{c}$ & $76.1 \mathrm{c}$ & $77.3 \mathrm{a}$ \\
\hline 15 April & $66.8 \mathrm{~d}$ & $66.3 \mathrm{~d}$ & $66.6 \mathrm{~d}$ & $66.5 \mathrm{~d}$ & $66.3 \mathrm{~d}$ & $66.5 \mathrm{~b}$ \\
\hline 1 May & $61.2 \mathrm{e}$ & $60.1 \mathrm{f}$ & 60.7 ef & $60.3 \mathrm{f}$ & $60.1 \mathrm{f}$ & $60.5 \mathrm{c}$ \\
\hline 15 May & $56.6 \mathrm{~g}$ & $55.7 \mathrm{~h}$ & $56.6 \mathrm{~g}$ & $55.6 \mathrm{~h}$ & $55.4 \mathrm{~h}$ & $56.0 \mathrm{~d}$ \\
\hline 1 June & $52.3 \mathrm{~m}-\mathrm{o}$ & $51.60-q$ & $51.9 n-p$ & $51.0 \mathrm{qr}$ & $51.3 p-r$ & $51.6 \mathrm{f}$ \\
\hline 15 June & $52.8 \mathrm{k}-\mathrm{m}$ & $51.8 n-q$ & $51.5 \mathrm{o}-\mathrm{r}$ & $51.7 \mathrm{o}-\mathrm{q}$ & $50.7 r$ & $51.7 \mathrm{f}$ \\
\hline 1 July & $52.6 \mathrm{I}-\mathrm{n}$ & $52.1 \mathrm{~m}-\mathrm{p}$ & 52.8 k-m & $51.7 \mathrm{o}-\mathrm{q}$ & $51.3 p-r$ & $52.1 \mathrm{f}$ \\
\hline 15 July & $55.3 \mathrm{~h}$ & $54.2 \mathrm{ij}$ & $54.3 \mathrm{i}$ & $53.4 \mathrm{j}-\mathrm{I}$ & $53.6 \mathrm{i}-\mathrm{k}$ & $54.2 \mathrm{e}$ \\
\hline Average & $59.6 \mathrm{a}$ & $58.5 \mathrm{c}$ & $59.0 \mathrm{~b}$ & $58.4 \mathrm{~cd}$ & $58.1 \mathrm{~d}$ & \\
\hline \multicolumn{2}{|c|}{ Coef. of variation (\%) } & 1.46 & & & & \\
\hline \multicolumn{2}{|c|}{ Variety LSD $_{(0.05)}$} & $0.82^{* *}$ & & & & \\
\hline \multicolumn{2}{|c|}{ Sow. time LSD $(0.05)$} & $0.28^{* \star}$ & & & & \\
\hline \multicolumn{2}{|c|}{ Sow. time $\times$ var. $\operatorname{LSD}_{(0.0)}$} & $0.80^{* *}$ & & & & \\
\hline
\end{tabular}

** significant at the level of 0.01 ; * significant at the 0.05 level

Table 5 - Average plant height $(\mathrm{cm})$ values of some sweet corn varieties of different sowing times

\begin{tabular}{|c|c|c|c|c|c|c|}
\hline \multirow[b]{2}{*}{ Sowing time } & \multicolumn{5}{|c|}{ Varieties } & \multirow{2}{*}{ Average } \\
\hline & 'Merit' & 'Lumina’ & 'Jubilee' & 'Vega' & $\begin{array}{l}\text { 'Sakarya' } \\
\text { composite }\end{array}$ & \\
\hline 1 April & $177.5 \mathrm{i}-\mathrm{k}$ & $165.8 \mathrm{~m}$ & $183.8 f-i$ & $152.7 n$ & $187.8 \mathrm{~d}-\mathrm{g}$ & $173.5 \mathrm{c}$ \\
\hline 15 April & $186.8 \mathrm{e}-\mathrm{h}$ & $179.9 \mathrm{~g}-\mathrm{j}$ & $186.9 \mathrm{e}-\mathrm{h}$ & $162.2 \mathrm{~m}$ & $193.7 c-e$ & $181.9 \mathrm{bc}$ \\
\hline 1 May & $206.4 a$ & $179.1 \mathrm{~h}-\mathrm{j}$ & 199.8a-c & $174.9 \mathrm{j}-\mathrm{I}$ & $205.8 a$ & $193.2 a$ \\
\hline 15 May & $202.2 a-c$ & $185.4 \mathrm{e}-\mathrm{i}$ & $188.9 d-f$ & $165.6 \mathrm{~m}$ & $205.7 a$ & 189.6ab \\
\hline 1 June & $196.2 b-d$ & $185.8 \mathrm{e}-\mathrm{i}$ & 201.3a-c & $174.5 \mathrm{j}-\mathrm{I}$ & $207.8 a$ & $193.1 \mathrm{a}$ \\
\hline 15 June & 196.1b-d & $189.7 d-f$ & $190.1 d-f$ & $162.7 \mathrm{~m}$ & $202.5 a b$ & 188.1ab \\
\hline 1 July & $184.4 \mathrm{f}-\mathrm{i}$ & $179.7 \mathrm{~g}-\mathrm{j}$ & 201.7a-c & $167.8 \mathrm{Im}$ & $196.1 b-d$ & 185.9ab \\
\hline 15 July & $207.0 a$ & $185.8 \mathrm{e}-\mathrm{i}$ & 203.9ab & $169.3 \mathrm{k}-\mathrm{m}$ & 202.1a-c & $193.6 a$ \\
\hline Average & $194.6 b$ & $181.3 \mathrm{c}$ & $194.5 b$ & $166.2 d$ & $200.2 a$ & \\
\hline \multicolumn{2}{|c|}{ Coef. of variation (\%) } & 4.96 & & & & \\
\hline \multicolumn{2}{|c|}{ Sow. time LSD } & $10.32^{*}$ & & & & \\
\hline \multicolumn{2}{|l|}{ Variety LSD } & $3.12^{* *}$ & & & & \\
\hline \multicolumn{2}{|c|}{ Sow. time $\times$ var. LSD } & $8.64^{*}$ & & & & \\
\hline
\end{tabular}

** significant at the level of $0.01 ;{ }^{*}$ significant at the 0.05 level

The importance of sowing time and sowing time $\times$ variety interactions revealed that there was a significant difference between the varieties for plant height and that the varieties were affected by the sowing time. In a similar study conducted with sweet corn varieties in Kahramanmaraş conditions, the height of the plant increased due to delayed sowing dates (Cesurer, 1995; Cesurer and Ulger, 1997 b). Akman and Sencar (1991) 
pointed out that plant height decreased in early sowing. Sencer et al. (1997) reported that plant height increased as sowing time was delayed in a sweet corn trial established in Tokat conditions. Lushinger and Camilo (2008), Alan et al. (2011) and Sönmez et al. (2013) reported significant differences between varieties for plant height, and Kula and Karadogan (2017) reported an increase in plant height in parallel with the delay of sowing time under cover conditions.

\section{First ear height (cm)}

For first ear height, the variety was significant at the level of 0.01 , and the sowing time was significant at the level of 0.05 , while the interaction of the variety $\times$ sowing time was not significant (Table 6).

Table 6 - Average first ear height values of some sweet corn varieties of different sowing times

\begin{tabular}{|c|c|c|c|c|c|c|}
\hline \multirow[b]{2}{*}{ Sowing time } & \multicolumn{5}{|c|}{ Varieties } & \multirow[b]{2}{*}{ Average } \\
\hline & 'Merit' & 'Lumina' & 'Jubilee' & 'Vega' & $\begin{array}{l}\text { 'Sakarya' } \\
\text { composite }\end{array}$ & \\
\hline 1 April & 66.28 & 44.44 & 54.83 & 43.22 & 61.61 & $54.07 b-d$ \\
\hline April15 & 71.33 & 50.67 & 59.44 & 49.06 & 65.72 & $59.24 \mathrm{a}$ \\
\hline 1 May & 74.44 & 44.44 & 53.00 & 49.44 & 67.17 & $57.70 \mathrm{a}-\mathrm{c}$ \\
\hline 15 May & 73.50 & 47.61 & 49.83 & 45.68 & 64.39 & $56.20 \mathrm{a}-\mathrm{d}$ \\
\hline 1 June & 71.54 & 48.83 & 53.40 & 47.72 & 68.61 & $58.02 \mathrm{ab}$ \\
\hline 15 June & 68.17 & 39.76 & 46.89 & 41.94 & 61.61 & $51.67 \mathrm{~d}$ \\
\hline 1 July & 63.94 & 43.56 & 50.72 & 47.44 & 60.39 & $53.21 \mathrm{~cd}$ \\
\hline 15 July & 76.28 & 47.39 & 56.83 & 50.00 & 67.28 & $59.55 \mathrm{a}$ \\
\hline Average & $70.68 \mathrm{a}$ & $45.83 \mathrm{~d}$ & $53.11 \mathrm{c}$ & $46.81 \mathrm{~d}$ & $64.59 \mathrm{~b}$ & \\
\hline \multicolumn{2}{|c|}{ Coef. of variation (\%) } & 11.59 & & & & \\
\hline \multicolumn{2}{|c|}{ Sow. time LSD } & $4.57^{*}$ & & & & \\
\hline \multicolumn{2}{|l|}{ Variety LSD } & $2.19^{* *}$ & & & & \\
\hline \multicolumn{2}{|c|}{ Sow. time $\times$ var. LSD } & Not signific & ant & & & \\
\hline
\end{tabular}

** significant at the level of $0.01 ;{ }^{*}$ significant at the 0.05 level

As shown in Table 6, the average values of first ear height for the sowing time changed between $51.67 \mathrm{~cm}$ (15 June) and $59.55 \mathrm{~cm}$ (15 July); the average values of the varieties varied between $45.83 \mathrm{~cm}$ ('Lumina') and $70.68 \mathrm{~cm}$ ('Merit'). The 15 April and 15 July sowings had the highest first ear heights, while the 15 June sowing had the lowest. The 'Merit' variety had the highest first ear height while 'Lumina' and 'Vega' had the lowest. Anil and Sezer (2003), as well as Öktem and Öktem (2006) reported significant differences between varieties for first ear height. Cesurer (1995) found that the 'Merit' variety had a higher first ear height than other varieties.

\section{Ear length (cm)}

For ear length, sowing time and variety were significant at the level of 0.01 , while the sowing time $\times$ variety interaction was significant at the level of 0.05 (Table 7) 
In Table 7, the average values of ear lengths for the sowing times were between $17.98 \mathrm{~cm}$ (1 July) and $20.83 \mathrm{~cm}$ (15 May); the average values for the varieties varied between 17.77 ('Sakarya' composite) and $20.22 \mathrm{~cm}$ ('Vega'). The average values of ear lengths for the sowing time $\times$ variety interactions varied between 15.41 (1 July $\times$ 'Merit') and $21.74 \mathrm{~cm}$ (15 May $\times$ 'Vega'). Meanwhile, the 15 May sowing time had the longest ears, while 1 June, 15 June, 1 July and 15 July sowing times had the shortest ears. The 'Vega', 'Lumina' and
'Jubilee' varieties had the longest ears, while 'Merit' and 'Sakarya' composite had the shortest ears. The 'Vega' $\times$ 15 May sowing time interactions had the longest ears, while the 'Merit' $\times$ 1 July sowing time interaction had the lowest ear lengths. The ear length is one of the important features to increase the yield and value of marketing. The findings obtained from the study showed that 'Lumina', 'Jubilee' and 'Vega' have long ears, while 'Merit' and 'Sakarya' Composite corn varieties have short ears.

Table 7 - Average ear length values of some sweet corn varieties of different sowing times

\begin{tabular}{lllllll}
\hline \multirow{2}{*}{ Sowing time } & \multicolumn{5}{c}{ Varieties } \\
\cline { 2 - 7 } & 'Merit' & 'Lumina' & 'Jubilee' & 'Vega' & $\begin{array}{l}\text { 'Sakarya' } \\
\text { composite }\end{array}$ & Average \\
\hline 1 April & $19.04 \mathrm{~h}-\mathrm{m}$ & $20.63 \mathrm{a}-\mathrm{g}$ & $19.87 \mathrm{e}-\mathrm{k}$ & $20.27 \mathrm{c}-\mathrm{i}$ & $19.13 \mathrm{~h}-\mathrm{m}$ & $19.79 \mathrm{~b}$ \\
\hline 15 April & $18.52 \mathrm{l}-\mathrm{p}$ & $20.82 \mathrm{a}-\mathrm{f}$ & $20.34 \mathrm{~b}-\mathrm{h}$ & $21.15 \mathrm{a}-\mathrm{e}$ & $18.28 \mathrm{~m}-\mathrm{p}$ & $19.82 \mathrm{~b}$ \\
\hline 1 May & $18.74 \mathrm{k}-\mathrm{o}$ & $19.67 \mathrm{f}-\mathrm{I}$ & $21.46 \mathrm{a}-\mathrm{c}$ & $21.26 \mathrm{a}-\mathrm{d}$ & $17.55 \mathrm{o}-\mathrm{q}$ & $19.74 \mathrm{~b}$ \\
\hline 15 May & $20.66 \mathrm{a}-\mathrm{g}$ & $21.63 \mathrm{ab}$ & $21.26 \mathrm{a}-\mathrm{d}$ & $21.74 \mathrm{a}$ & $18.84 \mathrm{j}-\mathrm{o}$ & $20.83 \mathrm{a}$ \\
\hline 1 June & $17.20 \mathrm{pq}$ & $18.89 \mathrm{i}-\mathrm{o}$ & $19.33 \mathrm{~g}-\mathrm{m}$ & $19.87 \mathrm{e}-\mathrm{k}$ & $17.30 \mathrm{pq}$ & $18.52 \mathrm{c}$ \\
\hline 15 June & $17.24 \mathrm{pq}$ & $19.88 \mathrm{~d}-\mathrm{I}$ & $19.51 \mathrm{f}-\mathrm{m}$ & $19.48 \mathrm{f}-\mathrm{m}$ & $17.60 \mathrm{n}-\mathrm{q}$ & $18.74 \mathrm{c}$ \\
\hline 1 July & $15.41 \mathrm{r}$ & $19.35 \mathrm{~g}-\mathrm{m}$ & $19.42 \mathrm{~g}-\mathrm{m}$ & $19.12 \mathrm{~h}-\mathrm{m}$ & $16.62 \mathrm{qr}$ & $17.98 \mathrm{c}$ \\
\hline 15 July & $16.50 \mathrm{qr}$ & $20.12 \mathrm{~d}-\mathrm{j}$ & $18.91 \mathrm{j}-\mathrm{n}$ & $18.90 \mathrm{j}-\mathrm{n}$ & $16.85 \mathrm{q}$ & $18.25 \mathrm{c}$ \\
\hline Average & $17.91 \mathrm{~b}$ & $20.12 \mathrm{a}$ & $20.01 \mathrm{a}$ & $20.22 \mathrm{a}$ & $17.77 \mathrm{~b}$ & \\
\hline Coef. of variation $(\%)$ & 7.48 & & & & \\
\hline Sow. time LSD & $0.79^{* *}$ & & & \\
\hline
\end{tabular}

** significant at the level of 0.01 ; * significant at the 0.05 level

Waligora (1997) reported that delayed sowing times reduced ear length. Alan et al. (2011) pointed out that ear length decreased during early cultivation. Öktem and Öktem (2006) reported that ear length changes due to environmental and genetic factors. Deng et al. (2009) stated that ear length is the most variable feature. Kara (2011) declared that ear length was affected by sowing time, Sönmez et al. (2013) pointed out that the ear height varies according to varieties, Kula and Karadogan (2017) stated that the fresh ear height varies between 10.2 and $14.0 \mathrm{~cm}$ according to the variety, 


\section{DETERMINING THE MOST APPROPRIATE PLANTING TIME FOR SWEET CORN}

Ağaçkesen and Öktem (2020) reported that the fresh ear length varies between 17.3 and $20.2 \mathrm{~cm}$.

\section{Ear diameter (mm)}

For ear diameter, the sowing time and variety were significant at the level of 0.01 , and the sowing time $\times$ variety interaction was significant at the level of 0.05 (Table 8).

From Table 8, the average values of sowing times were between $41.02 \mathrm{~mm}$ (1 May) and $45.08 \mathrm{~mm}$ (15 April); the values for the varieties varied between $41.69 \mathrm{~mm}$ ('Jubilee') and $45.05 \mathrm{~mm}$ ('Vega'). The average values of the sowing time $\times$ variety interactions varied between $38.96 \mathrm{~mm}$ (1 May $\times$ 'Jubilee') and $46.10 \mathrm{~mm}$ (15 April $x$ 'Merit'). While the 15 April and 15 July sowing times had high ear diameters, the 1 May sowing had the lowest ear diameters. The 'Vega' variety had the highest ear diameters, while the 'Jubilee' variety had the lowest. The 'Merit' $\times 15$ April and 'Vega' $\times 1$ July interactions had the highest ear diameters, while the 'Jubilee' $\times 1$ May interaction had the lowest. For ear diameter characteristics, the 'Lumina', 'Jubilee' and 'Sakarya' composite varieties were in the thin category, while the 'Vega' and 'Merit' varieties were in the thick category. The height and the diameter of the ear are important features, as they increase the yield and the marketing value of the ear.

The results reported by Harper (1994), Koçak and Köycü (1994), as well as Öktem and Öktem (1999) for ear diameter were similar to the results of our study. Lushinger and Camilo (2008), Kara (2011) stated that the diameter of the ear varies depending on sowing times and varieties.

Table 8 - Average ear diameter values of some sweet corn varieties of different sowing times

\begin{tabular}{lllllll}
\hline \multirow{2}{*}{ Sowing time } & \multicolumn{5}{c}{ Varieties } \\
\cline { 2 - 7 } & 'Merit' & 'Lumina' & 'Jubilee' & 'Vega' & $\begin{array}{l}\text { 'Sakarya' } \\
\text { composite }\end{array}$ & Average \\
\hline 1 April & $44.05 \mathrm{~b}-\mathrm{i}$ & $42.01 \mathrm{k}-\mathrm{o}$ & $41.97 \mathrm{l}-\mathrm{p}$ & $45.46 \mathrm{a}-\mathrm{c}$ & $42.58 \mathrm{~h}-\mathrm{n}$ & $43.21 \mathrm{~b}$ \\
\hline 15 April & $46.10 \mathrm{a}$ & $45.50 \mathrm{ab}$ & $44.58 \mathrm{a}-\mathrm{g}$ & $45.55 \mathrm{ab}$ & $43.70 \mathrm{e}-\mathrm{j}$ & $45.08 \mathrm{a}$ \\
\hline 1 May & $41.71 \mathrm{~m}-\mathrm{p}$ & $40.60 \mathrm{o}-\mathrm{r}$ & $38.96 \mathrm{r}$ & $43.08 \mathrm{~g}-\mathrm{m}$ & $40.73 \mathrm{o}-\mathrm{q}$ & $41.02 \mathrm{~d}$ \\
\hline $15 \mathrm{May}$ & $43.57 \mathrm{f}-\mathrm{I}$ & $41.27 \mathrm{n}-\mathrm{p}$ & $40.61 \mathrm{o}-\mathrm{r}$ & $45.40 \mathrm{a}-\mathrm{d}$ & $41.17 \mathrm{n}-\mathrm{p}$ & $42.40 \mathrm{bc}$ \\
\hline 1 June & $42.48 \mathrm{~h}-\mathrm{n}$ & $40.52 \mathrm{o}-\mathrm{r}$ & $39.43 \mathrm{qr}$ & $44.94 \mathrm{a}-\mathrm{f}$ & $40.32 \mathrm{p}-\mathrm{r}$ & $41.54 \mathrm{~cd}$ \\
\hline 15 June & $42.53 \mathrm{i}-\mathrm{n}$ & $43.73 \mathrm{c}-\mathrm{k}$ & $41.11 \mathrm{n}-\mathrm{q}$ & $44.75 \mathrm{a}-\mathrm{f}$ & $41.44 \mathrm{~m}-\mathrm{p}$ & $42.71 \mathrm{bc}$ \\
\hline 1 July & $43.72 \mathrm{e}-\mathrm{j}$ & $41.50 \mathrm{~m}-\mathrm{p}$ & $42.61 \mathrm{~h}-\mathrm{n}$ & $45.95 \mathrm{a}$ & $42.20 \mathrm{j}-\mathrm{o}$ & $43.19 \mathrm{~b}$ \\
\hline 15 July & $45.44 \mathrm{a}-\mathrm{c}$ & $43.77 \mathrm{~d}-\mathrm{j}$ & $44.28 \mathrm{~b}-\mathrm{g}$ & $45.26 \mathrm{a}-\mathrm{e}$ & $44.22 \mathrm{~b}-\mathrm{h}$ & $44.60 \mathrm{a}$ \\
\hline Average & $43.70 \mathrm{~b}$ & $42.36 \mathrm{c}$ & $41.69 \mathrm{~d}$ & $45.05 \mathrm{a}$ & $42.04 \mathrm{~cd}$ & \\
\hline Coef. of variation $(\%)$ & 4.13 & & & & \\
\hline Sowing time LSD & $1.13^{\star *}$ & & & & \\
\hline
\end{tabular}

${ }^{* *}$ significant at the level of $0.01 ;{ }^{*}$ significant at the 0.05 level 
Öktem and Öktem (2006) emphasised that the highest ear diameters were in the 'Martha' (45.83, 49.07 and $47.45 \mathrm{~mm}$ ) and 'Vega' (46.63 mm, 47.57 and $47.10 \mathrm{~mm}$ ) varieties, while Eşiyok and Bozokalfa (2005) reported that cultivation techniques affect the thickness of the ear. Fujino (1980), Anil and Sezer (2003) and Sönmez et al. (2013) reported that the thickness of the ear varied according to the variety.

\section{Number of ears per plant (unit/plant)}

For the number of ears per plant, sowing time was significant at the level of $p \leq 0.05$, and the variety was significant at the level of $p \leq 0.01$.
The sowing time $\times$ variety interaction was not significant.

From Table 9, the average values of sowing times varied between 0.88 plant $^{-1}$ and 1.07 plant $^{-1}$, and the average values for the varieties were between 0.90 plant $^{-1}$ ('Merit') and 1.05 plant $^{-1}$ ('Jubilee'). The 1 April and 15 April sowing times had the highest numbers of ears per plant, while the sowing times of 1 June and 1 July had the lowest. While 'Jubilee' had the highest numbers of ears per plant, 'Merit' was the lowest for this trait. The number of ears per plant decreased as the sowing times were delayed, and the 'Jubilee' variety stood out.

Table 9 - Average number of ears per plant values of some sweet corn varieties of different sowing times

\begin{tabular}{|c|c|c|c|c|c|c|}
\hline \multirow[b]{2}{*}{ Sowing time } & \multicolumn{5}{|c|}{ Varieties } & \multirow[b]{2}{*}{ Average } \\
\hline & 'Merit' & 'Lumina' & 'Jubilee' & 'Vega' & $\begin{array}{l}\text { 'Sakarya' } \\
\text { composite }\end{array}$ & \\
\hline 1 April & 0.99 & 1.06 & 1.11 & 1.04 & 1.15 & $1.07 \mathrm{a}$ \\
\hline 15 April & 0.98 & 1.01 & 1.12 & 1.09 & 1.09 & $1.05 \mathrm{a}$ \\
\hline 1 May & 0.84 & 1.11 & 1.11 & 1.03 & 0.99 & $1.01 \mathrm{ab}$ \\
\hline 15 May & 0.91 & 1.07 & 1.00 & 0.94 & 1.11 & $1.00 \mathrm{ab}$ \\
\hline 1 June & 0.77 & 0.77 & 0.77 & 0.77 & 0.77 & $0.89 \mathrm{c}$ \\
\hline 15 June & 0.90 & 0.96 & 1.06 & 0.93 & 0.93 & $0.95 \mathrm{bc}$ \\
\hline 1 July & 0.81 & 0.89 & 1.02 & 0.85 & 0.85 & $0.88 \mathrm{c}$ \\
\hline 15 July & 0.99 & 1.01 & 1.05 & 0.96 & 1.03 & $1.00 \mathrm{ab}$ \\
\hline Average & $0.90 \mathrm{c}$ & $1.00 \mathrm{~b}$ & $1.05 \mathrm{a}$ & $0.97 \mathrm{~b}$ & $1.00 \mathrm{~b}$ & \\
\hline \multicolumn{2}{|c|}{ Coef. of variation (\%) } & 12.42 & & & & \\
\hline \multicolumn{2}{|c|}{ Sowing time LSD } & $0.09^{*}$ & & & & \\
\hline \multicolumn{2}{|c|}{ Variety LSD } & $0.04^{\star *}$ & & & & \\
\hline \multicolumn{2}{|c|}{ Sow. time $\times$ var. LSD } & Not signific & & & & \\
\hline
\end{tabular}

Different findings were obtained from Cesurer and Ülger (1997), Bozokalfa et al. (2004), as well as Eşiyok and Bozokalfa (2005), who reported that there were no differences between sowing times and varieties for the number of ears per plant. Our findings were supported by the findings of Waligora (1997), who reported that the number of ears per 


\section{DETERMINING THE MOST APPROPRIATE PLANTING TIME FOR SWEET CORN}

plant decreased with the delay of planting. Our findings were also supported by the findings of Turgut and Balci (2001), who reported that there were differences between planting times and varieties. This is supported by the findings of Tuncay et al. (2005), who reported that early sowing increased the number of ears per plant, and it is also supported by the findings of Lushsinger and Camilo (2008), who stated that the number of ears per plant differed with sowing times.

\section{Fresh husked ear yield $\left(\mathrm{kg} \mathrm{ha}^{-1}\right)$}

The sowing time, variety and sowing time $\times$ variety interaction was significant at the level of 0.01 for fresh ear yield with husked per hectare (Table 10).

From Table 10, the average values of fresh husked ear yield for the different sowing times were between
$10587.4 \mathrm{~kg} \mathrm{ha}^{-1} \quad(1 \quad$ June $)$ and $16984.1 \mathrm{~kg} \mathrm{ha}^{-1}$ (15 April); the average values of the varieties were between $11736.2 \mathrm{~kg} \mathrm{ha}^{-1}$ ('Merit') and $15470.1 \mathrm{~kg} \mathrm{ha}^{-1}$ ('Vega'). The sowing time $\times$ variety interactions were between $8541.7 \mathrm{~kg} \mathrm{ha}^{-1}$ (1 June $\times$ 'Merit') and $19396.8 \mathrm{~kg} \mathrm{ha}^{-1}$ (15 April $\times$ 'Vega'). The 1 April, 15 April and 1 May sowing times and the 'Vega' variety had the highest fresh, husked ear yield per hectare, while the 1 June planting, 'Merit' and 'Sakarya' composite varieties had the lowest. The 'Vega' $\times 15$ April interaction had the highest fresh, husked ear yield per hectare, while the 'Merit' $\times 1$ June sowing interaction had the lowest. For fresh ears with husks yield, the 'Jubilee' variety can be recommended for 15 July, while the 'Vega' variety can be recommended for other sowing times (1 April-15 July).

Table 10 - Average fresh ear yield with husked values of some sweet corn varieties of different sowing times

\begin{tabular}{|c|c|c|c|c|}
\hline \multirow{2}{*}{$\begin{array}{l}\text { Sowing } \\
\text { time }\end{array}$} & \multicolumn{4}{|l|}{ Varieties } \\
\hline & 'Merit' & 'Lumina' & 'Jubilee’ & $\begin{array}{l}\text { 'Sakarya' } \\
\text { composite }\end{array}$ \\
\hline 1 April & $14587.2 \mathrm{e}-\mathrm{h}$ & $16325.3 \mathrm{c}-\mathrm{e}$ & 16083.3 c-e 17055.5 bc & 16230.1 c-e 16056.3 a \\
\hline 15 April & $15436.4 \mathrm{c}-\mathrm{g}$ & $18412.6 \mathrm{ab}$ & 16785.6 b-d 19396.8 a & 14888.9 d-g $16984.1 \mathrm{a}$ \\
\hline 1 May & $11404.7 \mathrm{k}-\mathrm{p}$ & $15396.8 \mathrm{c}-\mathrm{g}$ & $15595.1 \mathrm{c}-\mathrm{f} 19380.9 \mathrm{a}$ & $13603.1 \mathrm{~g}-\mathrm{j} 15076.1 \mathrm{a}$ \\
\hline 15 May & 12071.4 j-o & $12920.6 \mathrm{~h}-\mathrm{k}$ & 11523.7 k-p 14595.2 e-h & 12214.2 i-o $12665.0 \mathrm{~b}$ \\
\hline 1 June & $8541.7 \mathrm{q}$ & $9895.5 \mathrm{pq}$ & $10747.5 \mathrm{l}-\mathrm{p} \quad 14119.0 \mathrm{f}-\mathrm{i}$ & $9634.1 \mathrm{pq} \quad 10587.4 \mathrm{c}$ \\
\hline 15 June & $10595.2 \mathrm{n}-\mathrm{q}$ & $10597.1 \mathrm{~m}-\mathrm{q}$ & 11277.7 k-p 12482.9 i-n & 10309.4 o-q 11052.5 bc \\
\hline 1 July & $9658.6 \mathrm{pq}$ & $12571.4 \mathrm{i}-\mathrm{m}$ & 12579.3 i-m 12746.0 h-I & $10071.4 \mathrm{pq} 11525.3 \mathrm{bc}$ \\
\hline 15 July & $11595.2 \mathrm{k}-\mathrm{p}$ & $11555.5 \mathrm{k}-\mathrm{p}$ & 14706.3 e-h $13984.1 \mathrm{f}-\mathrm{j}$ & 10444.4 o-q 12457.1 bc \\
\hline Average & $11736.2 \mathrm{c}$ & $13459.3 \mathrm{~b}$ & $13662.3 \mathrm{~b} \quad 15470.1 \mathrm{a}$ & $12174.4 \mathrm{c}$ \\
\hline Coef. of $v$ & variation $(\%)$ & 15.77 & & \\
\hline Sowing ti & ime LSD & $3880.8^{* \star}$ & & \\
\hline Variety L & SD & $708.7^{* *}$ & & \\
\hline Sow. time & e $\times$ var. LSD & $1960.6^{* *}$ & & \\
\hline
\end{tabular}

${ }^{* *}$ significant at the level of $0.01 ;{ }^{*}$ significant at the 0.05 level 
The importance of sowing time $x$ variety interactions for husked fresh ear yield indicated that the varieties were affected differently by the sowing time. The highest yield was obtained for the 'Vega' variety at all sowing times. The high yield in sowing between 1 April and 1 May indicates that planting can be done between these dates, and the 'Vega' variety, with the highest yield, can be planted. For the sowing times, the yield decreased since 1 May and reached the lowest level in the 1 June sowing. Our findings are supported by the studies of Olsen et al. (1990), Sari et al. (1997), Sencer et al. (1999), Eşiyok and Bozokalfa (2005), as well as Öktem and Öktem (2006). Eser and Soylu (2020) emphasised that when the ears are harvested, the husked yield is a significant feature since the sale from the producer to the marketer is done without going to the consumer.

Fresh unhusked ear yield $\left(\mathrm{kg} \mathrm{ha}^{-1}\right)$

The sowing time, variety and the sowing time $\times$ variety interaction were significant at the level of 0.01 for unhusked fresh ear yield per hectare (Table 11).

In Table 11, the average values of planting times for unhusked fresh ear yield were between $6135.3 \mathrm{~kg} \mathrm{ha}{ }^{-1}$ (1 June) and $11687.6 \mathrm{~kg} \mathrm{ha}^{-1}$ (1 April), and the average values of the varieties were between $7530.9 \mathrm{~kg} \mathrm{ha}^{-1}$ ('Sakarya' composite) and $10383.8 \mathrm{~kg} \mathrm{ha}{ }^{-1}$ ('Vega'). The average values of sowing time $x$ variety interactions varied between $5065.0 \mathrm{~kg} \mathrm{ha}^{-1}$ (1 June $\times$ 'Sakarya' composite) and $13485.7 \mathrm{~kg} \mathrm{ha}^{-1}$ (15 April × 'Vega').

Table 11 - Average fresh ear yield with unhusked values of some sweet corn varieties of different sowing times

\begin{tabular}{|c|c|c|c|c|c|c|}
\hline \multirow{2}{*}{$\begin{array}{l}\text { Sowing } \\
\text { time }\end{array}$} & \multicolumn{5}{|c|}{ Varieties } & \multirow[b]{2}{*}{ Average } \\
\hline & 'Merit' & 'Lumina' & ‘Jubilee’ & 'Vega' & $\begin{array}{l}\text { 'Sakarya' } \\
\text { composite }\end{array}$ & \\
\hline 1 April & $10809.5 d-f$ & $10777.7 d-f$ & $11273.7 c-e$ & 11341.2c-e & e10468.2d-g & $10934.1 \mathrm{ab}$ \\
\hline April15 & $11674.5 b-d$ & 1223.0a-c & $11761.8 b-d$ & $13485.7 a$ & $9285.7 g-j$ & $11687.6 a$ \\
\hline 1 May & 8158.7j-m & $8872.9 \mathrm{~h}-\mathrm{k}$ & 10126.9e-h & 12811.0ab & 8333.3j-m & $9660.6 \mathrm{bc}$ \\
\hline 15 May & $8555.5 i-m$ & $7365.0 \mathrm{mo}$ & 7031.7o-q & $9190.4 \mathrm{~g}-\mathrm{j}$ & 7031.7o-q & $7834.8 d$ \\
\hline 1 June & $5622.7 q-s$ & 5171.0rs & $5834.6 p-s$ & $8983.3 \mathrm{~h}-\mathrm{j}$ & $5065.0 \mathrm{~s}$ & $6135.3 e$ \\
\hline 15 June & 8031.7j-m & $7064.40-q$ & $7587.2 \mathrm{k}-\mathrm{o}$ & $8626.9 \mathrm{i}-\mathrm{m}$ & $6579.30-r$ & 7577.9de \\
\hline 1 July & 7142.8op & $7507.8 \mathrm{I}-\mathrm{o}$ & $8730.1 \mathrm{i}-\mathrm{I}$ & $8885.6 h-k$ & 6420.6o-s & $7737.4 d$ \\
\hline 15 July & $8801.5 \mathrm{~h}-\mathrm{I}$ & $8063.4 \mathrm{j}-\mathrm{m}$ & $10674.5 d-f$ & 9746.0f-i & 7063.4op & $8869.8 \mathrm{~cd}$ \\
\hline Average & $8599.6 c$ & $8381.6 \mathrm{c}$ & $9127.6 \mathrm{~b}$ & $10383.8 a$ & $7530.9 d$ & \\
\hline \multicolumn{2}{|c|}{ Coef. of variation (\%) } & 16.52 & & & & \\
\hline \multicolumn{2}{|c|}{ Sowing time LSD } & $1424.7^{* *}$ & & & & \\
\hline \multicolumn{2}{|c|}{ Variety LSD } & $492.4^{\star \star}$ & & & & \\
\hline \multicolumn{2}{|c|}{ Sow. time $\times$ var. LSD } & $1362.4^{* *}$ & & & & \\
\hline
\end{tabular}


While the 15 April sowing had the highest fresh unhusked ear yield per hectare, the 1 June planting was the lowest. The 'Vega' variety was the highest for the unhusked fresh ear yield value per hectare, and the 'Sakarya' composite was the lowest. While the 'Vega' $\times 15$ April sowing time interaction had the highest yield, the 'Sakarya' composite $\times 1$ June sowing time interaction had the lowest.

The importance of sowing time $x$ variety interaction for unhusked ear yield shows that varieties were affected differently by sowing time. The highest yield was obtained for the 'Vega' variety, and the lowest yield was obtained for the 'Sakarya' composite variety. The high yield from planting between 1 April and 1 May indicates that sowing should be done between these dates. For unhusked fresh ear yield, the 'Jubilee' variety can be recommended for 15 July, while the 'Vega' variety can be recommended for other sowing times (1 April to 15 July). For sowing times, the yields were high between the 1 April and 1 May sowing times, and they declined from 1 May and reached the lowest level at the 1 June sowing, after which, it rose again. The effect of the high temperature factor in the region is seen during the planting times.

Sari et al. (1997), Turgut and Balci (2002), Anil and Sezer (2003), Eşiyok and Bozokalfa (2005), Öktem and Öktem (2006), as well as Alan et al. (2011) reported that for unhusked ear yield, sowing time and variety factors, as well as the sowing time $\times$ cultivar interaction had significant effects. Atar and Kara (2017) reported that fresh ear yield per hectare was 11109$12894 \mathrm{~kg} \mathrm{ha}^{-1}$, Kula and Karadoğan (2017) reported that fresh ear yield per hectare was $8599-14585 \mathrm{~kg} \mathrm{ha}^{-1}$ and Ağaçkesen and Öktem (2020) reported that fresh ear yield ranged between $11032 \mathrm{~kg} \mathrm{ha}^{-1}$ and $1888 \mathrm{~kg} \mathrm{ha}^{-1}$. Eser and Soylu (2020) stated that the most important goal in sweet corn production is high yield, and they obtained the highest yield from the 'Vega' variety in their study, which supports our findings.

\section{Marketable number of ears per plant (number ha')}

The sowing time, variety and sowing time $\times$ variety interaction were significant at the level of 0.01 for the marketable number of ears (Table 12).

According to Table 12, the average yield values for the sowing times were between 21728.5 pieces $^{-1}$ ( 1 June) and 53357.1 pieces ha $^{-1}$ (15 April); the average values of the varieties varied between 31085.7 pieces $\mathrm{ha}^{-1}$ ('Lumina') and 44957.1 pieces $\mathrm{ha}^{-1}$ ('Vega'). The average values of sowing time $\times$ cultivar interactions varied between 12570.0 pieces $\mathrm{ha}^{-1}$ $(1$ June $\times$ 'Lumina') and 61585.7 pieces ha $^{-1}$ (15 April $\times$ 'Vega'). While 1 April and 15 April sowing periods had the highest marketable ear numbers, the 1 June cultivation had the lowest. The 'Vega' variety was the highest for marketable ear numbers, and the 'Lumina' variety was the lowest. The 'Vega' $\times 15$ April interaction had the highest numbers of marketable ears, while the 'Lumina' $x$ 1 June interaction had the lowest. For the marketable number of ears, the 


\section{Sevda KILINÇ ET AL.}

'Jubilee' variety can be recommended for early (1 April) and late sowing (1-15 July), while the 'Vega' variety can be recommended for other sowing times (between 1 July-15 April). Our findings are supported by ManguelCrespo (1977), as well as Domenech and Manguel-Crespo (1977), who reported that there were differences between the cultivation times and varieties for marketable ear numbers, in addition to Kula and Karadoğan (2017), who reported that there was a difference between varieties, as well as by Sari and Abak. (1997), who reported that sowing times affected the yield and quality of the ears. Our findings differ from Kwabiah (2004), who reported that there was no difference between varieties for total marketable yield.

\section{Table 12 - Average marketable number of ears values of some sweet corn varieties of different sowing times}

\begin{tabular}{|c|c|c|c|c|c|c|}
\hline \multirow{2}{*}{$\begin{array}{l}\text { Sowing } \\
\text { time }\end{array}$} & \multicolumn{5}{|c|}{ Varieties } & \multirow[b]{2}{*}{ Average } \\
\hline & 'Merit' & 'Lumina' & 'Jubilee' & 'Vega' & $\begin{array}{l}\text { 'Sakarya' } \\
\text { composite }\end{array}$ & \\
\hline 1 April & 51742.8 b-e & $44114.2 \mathrm{f}-\mathrm{h}$ & $57928.5 \mathrm{ab}$ & $54600.0 \mathrm{~b}-\mathrm{d}$ & $50785.7 \mathrm{c}-\mathrm{f}$ & $51828.5 \mathrm{a}$ \\
\hline 15 April & $53328.5 \mathrm{~b}-\mathrm{d}$ & d 49042.8 c-f & $53957.1 \mathrm{~b}-\mathrm{d}$ & $61585.7 \mathrm{a}$ & $48885.7 \mathrm{c}-\mathrm{f}$ & $53357.1 \mathrm{a}$ \\
\hline 1 May & $34757.1 \mathrm{j}-\mathrm{m}$ & $35071.4 \mathrm{j}-\mathrm{I}$ & $48571.4 \mathrm{~d}-\mathrm{g}$ & 55542.8 a-c & $40628.5 \mathrm{~h}-\mathrm{j}$ & $42914.2 \mathrm{~b}$ \\
\hline 15 May & 35228.5 i-I & $20000.0 \mathrm{pq}$ & $26657.1 n-p$ & 35714.2 i-k & $28085.7 \mathrm{~m}-\mathrm{o}$ & $29142.8 \mathrm{c}$ \\
\hline 1 June & 22528.5 o-q & $12570.0 \mathrm{r}$ & $18485.7 \mathrm{qr}$ & $35228.5 \mathrm{i}-\mathrm{I}$ & $19828.5 \mathrm{q}$ & $21728.5 \mathrm{~d}$ \\
\hline 15 June & $40628.5 \mathrm{~h}-\mathrm{j}$ & $27157.1 \mathrm{no}$ & 30785.7 k-n & 35871.4 i-k & 30471.4 k-n & 32985.7 c \\
\hline 1 July & $41900.0 \mathrm{~g}-\mathrm{i}$ & 31900.0 k-n & $44600.0 \mathrm{f}-\mathrm{h}$ & $41100.0 \mathrm{~h}-\mathrm{j}$ & $34914.2 \mathrm{j}-\mathrm{I}$ & $38885.7 \mathrm{~b}$ \\
\hline 15 July & 45385.7 e-h & 28885.7 I-o & 45385.7 e-h & $40000.0 \mathrm{~h}-\mathrm{j}$ & $36814.2 \mathrm{i}-\mathrm{k}$ & $39300.0 \mathrm{~b}$ \\
\hline Average & $40685.7 \mathrm{~b}$ & $31085.7 \mathrm{~d}$ & $40800.0 \mathrm{~b}$ & $44957.1 \mathrm{a}$ & $36300.0 \mathrm{c}$ & \\
\hline \multicolumn{7}{|c|}{$\begin{array}{ll}\text { Coef. of var. (\%) } & 18.48 \\
\end{array}$} \\
\hline \multicolumn{7}{|c|}{$\begin{array}{ll}\text { Sowing time LSD } \quad 5485.7^{* *}\end{array}$} \\
\hline \multicolumn{7}{|c|}{$\begin{array}{ll}\text { Variety LSD } & 2428.6^{* *} \\
\end{array}$} \\
\hline \multicolumn{7}{|c|}{ S. time $\times$ var. LSD } \\
\hline
\end{tabular}

** significant at the level of 0.01 ; * significant at the 0.05 level

\section{CONCLUSIONS}

Assignment of optimum sowing date for sweet corn is very important for better crop yields and the marketable number of ears. The present study showed that planting dates had a significant effect on fresh ear yield and yield components. Our results show that the most suitable planting dates for sweet corn may be between 1 and 15 April in Diyarbakır ecology and similar ecological regions.
Moreover, the results indicate that the highest fresh unhusked and husked ear yields and marketable number of ears were obtained from the 'Vega' variety for the 15 April sowing, and the 'Jubilee' variety can be recommended for July sowings as the second crop in Diyarbakır conditions.

Assignment of optimum sowing date for sweet corn is very important for better crop yields and marketable number of ears. The present study showed that planting dates had a 


\section{DETERMINING THE MOST APPROPRIATE PLANTING TIME FOR SWEET CORN}

significant effect on fresh ear yield and yield components. Our results show that the most suitable planting dates for sweet corn may be between April 1 and April 15 in Diyarbakir ecology and similar ecological regions. Moreover, the results indicate that the highest fresh unhusked and husked ear yield and marketable number of ears are obtained from Vega variety on April 15 sowing and Jubilee variety can be recommended for July sowings as second crop in Diyarbakır conditions.

\section{REFERENCES}

Anonymous (2010). Diyarbakır 2010 yilı Meteoroloji Bülteni. Diyarbakır Meteoroloji Müdürlüğü, Diyarbakır, https://www.mgm.gov.tr/

Anonymous (2011). Diyarbakır 2011 yılı Meteoroloji Bülteni. Diyarbakır Meteoroloji Müdürlüğ̈̈, Diyarbakır, https://www.mgm.gov.tr/

Anonymous (2012). Diyarbakır 2012 yılı Meteoroloji Bülteni. Diyarbakır Meteoroloji Müdürlügü, Diyarbakır, https://www.mgm.gov.tr/

Anonymous (1991). Descriptors for maize. International Maize and Wheat Improvement Center, Mexico City (CIMMYT)/International Board for Plant Genetic Resources, Rome (IBPGR).

Anonymous (2019). Tarımsal Değerleri Ölçme Denemeleri Teknik Talimatı (Mısır-Zea mays L.). T.C. Tarım ve Orman Bakanlığı Tarımsal Üretim ve Geliştirme Gen. Md., Tohumluk Tescil ve Sertifikasyon Merkezi Md., Ankara.

Ağaçkesen, M.N. ve Öktem, A. (2020). Farklı Zamanlarda Yapılan Hasadın Merit Tatıı Mısır Çeşidinde (Zea mays L. saccharata Sturt) Taze Koçan Verimi ve Bazı Verim Unsurlarına Etkisi. KSÜ Tarım ve Doğa Derg., 23(1): 69-76, 2020, https://doi.org/ 10.18016/ksutarimdoga.
Akman, Z. ve Sencar, Ö. (1991). Şeker Mısırında (Zea mays L. var. saccharata) Ekim Sıklığı ve Farklı Ekim Zamanlarının Verim ve Diğer Agronomik Karakterler Üzerine Etkileri. C.Ü. Tokat Zir. Fak. Dergisi, 7: 25-36.

Alan, Ö., Sönmez, K. Budak, Z., Kutlu İ. ve Ayter, N.G. (2011). Eskişehir Ekolojik Koşullarında Ekim Zamanının Şeker Mısııın (Zea mays saccharata Sturt.) Verim ve Tarımsal Özellikleri Üzerine Etkisi. Selçuk Tarım ve Gıda Bilimleri Dergisi, Cilt 25, Sayı 4, http://sjafs.selcuk.edu.tr/sjafs

Anıl, H. \&Sezer, I. (2003). A study on the effects different sowing time and transplanting on the yield, yield components and some quality characteristics in sweet corn at Çarşamba Plain. O.M.U. Ziraat Fak. Dergisi, 18(2), 17-23.

Atar, B. ve Kara, B. (2017). Şeker mısırın taze koçan verimi ve bazı koçan özelliklerine farklı ekim derinliklerinin etkisi. Derim, 34(2):182-185, https:// doi.org/10.16882/derim.2017.286549

Bozokalfa, M K., Eşiyok, D. ve Uğur, A. (2004). Ege Bölgesi Koşullarında Ana ve İkinci Ürün Bazı Hibrit Şeker Mısır (Zea mays L. var. saccharata) Çeşitlerinin Verim Kalite ve Bitki Özelliklerinin Belirlenmesi, Ege Üniv. Ziraat Fak. Derg., 2004, 41(1):11-19 ISSN 1018-885, dergipark.org.tr

Cesurer L. ve Ülger, A.C. (1997a). Taze Koçan Olarak Değerlendirilen Şeker Mısırının Silajık Bitki olarak Üretime Girmesi. Türkiye I. Silaj Kongresi, 1719 Eylül 1997, Bursa, TMMOB Ziraat Mühendisleri Odası ve Uludağ Üniversitesi Ziraat Fakültesi Zootekni Bölümü, sayfa: $255-260$.

Cesurer L. \& Ülger, A.C. (1997b). Farklı ekim zamanlarının bazı şeker mısır çeşitleri üzerindeki etkisi. II. Tarla Bitkileri Kongresi, 25-29 Eylül, sayfa:134-138, Samsun.

Cesurer, L. (1995). Kahramanmaraş koşullarında ekim zamanı ve ekim sıklığının şeker mısırında taze koçan verimine ve diğer bazı tarımsal ve 
bitkisel özelliklere etkisi. Çukurova Üniversitesi Fen Bilimleri Enstitüsü Tarla Bitkileri Anabilim Dalı, Doktora Tezi, 205 sayfa, Adana.

Çetinkol, M. (1989). Tatlı Mısır Üretimi. Hasat Aylık Tarım Dergisi, İstanbul.

Deng, R., Wang, Y., Zhen, C. \& Zhou, Q. (2009). Effect of different sowing date on the growth and development of super sweet corn. http://en.cnki.com. cn/Article_en/CJFDTOTAL-FSDX20 0903003.h. htm.

Domenech, J. O. \& Mangual-Crespo, G. (1977). Performance of sweet corn varieties and their response to planting season. Journal of Agriculture of the University of Puerto Rico, 61(2): 170-174.

Erdal, Ş. ve Pamukçu, M. (2005). Tatlı misır (Zea mays L. var. saccharata Sturt.). Derim, 22(2), 41-46, dergipark.org.tr

Eser, C. \& Soylu S. (2020). Determination of fresh ear yield and some agronomic properties of sweet corn varieties in Central Anatolia conditions, Journal of Bahri Dagdas Crop Research, 9 (2): 147-157.

Eşiyok, D. ve Bozokalfa, M.K. (2005). Ekim ve Dikim Zamanlarının Tatlı Mısırda (Zea mays L.var. saccharata) Verim ve Koçanın Bazı Agronomik Karakterleri Üzerine Etkisi, Ege Üniv. Ziraat Fak. Derg. 42(1):35-46, ISSN 1018-8851, https://dergipark.org.tr/tr/ download/article-file/59142

Fujino, M. (1980). The classification and ecologic characters of commercial cultivars of swet corn. Bulletin of the Chugoku National Agricultural Experiment Station, 27:49-58.

Harper, F. (1994). Swet corn trials spring \& fall,1993. Dept. of Agr.Fisheries and Parks, 65(1): 1-6, Bermuda.

Kara, B. (2011). Fresh ear yield and growing degree-days of sweet corn in different sowing dates in Southwestern Anatolia Region. Turkish Journal of Field Crops, 16(2): 166-171, https://dergipark.org.tr/tr/ pub/tjfc/issue/17125/179103
Khan, Z.H., Khalil, S.K., Shaheen, N., Khalil, I.H., Ikramul, H., Iftikhar, A., Asad, A. \& Khan, M.Y. (2009). Phenology and yield of sweet corn landraces influenced by planting dates. Sarhad Journal of Agriculture, 25 (2), 153-157, researchgate.net.

Khan, Z.H., Khalıl, S.K., Farhatullah, Khan, M.Y., Israr, M. \& Abdulbasir. (2011). Selecting optimum planting date for sweet corn in Peshawar, Pakistan Sarhad J. Agric., Vol.27, No.3, researchgate.net.

Kula, N. ve Karadoğan, T. (2017). Örtü Altı Koşullarında Yetiştirilen Şeker Mısırı (Zea mays saccharata Sturt.) Çeşitlerinde Uygun Dikim Zamanlarının Belirlenmesi. Süleyman Demirel Üniversitesi Ziraat Fakültesi Dergisi, 12(1):39-48, 2017, https://dergipark.org.tr/en/download/a rticle-file/521010

Kwabiah, A.B. (2004). Economic evaluation of production methods for sweet corn in a cool climate. Journal of Vegetable Crop Production, 10(2): 73-87, Taylor \& Francis.

Luchsinger, L.A. \& Camilo, F.F. (2008). Sweet corn cultivars and their behaviour with different sowing dates in the 6th Region of Chile. IDESIA, 26(2): 4552.

Mangual-Crespo, G. (1977). Yield of two sweet corn varieties and two hybrids in the Isabella area. Journal of Agriculture of University of Puerto Rico, 61(2): 175-178, https://doi.org/ 10.46429/jaupr.v61i2.10455

Mehta B. K., Hossain F., Muthusamy V., Zunjare R. U., Sekhar J. C. \& Gupta Hari S. (2017). Analyzing the role of sowing and harvest time as factors for selecting super sweet (sh2sh2) corn hybrids, Indian J. Genet., 77(3): 348-356, https://doi.org/ 10.5958/0975-6906.2017.00047.5

Olsen, J.K., Blight, G.W. \& Gillespie, D. (1990). Comparison of yield, cob characteristics and sensory quality of six super sweet (sh2) corn cultivars grown in a subtropical environment. Australian Journal of Experimental 


\section{DETERMINING THE MOST APPROPRIATE PLANTING TIME FOR SWEET CORN}

Agriculture, 30, 3, https://doi.org/ 10.1071/ea990038

Öktem, A. ve Öktem, A.G. (1999). Bazı şeker mısır çeşitlerinin (Zea mays saccharata Sturt) taze koçan ve tane verimleri ile önemli tarımsal karakterlerinin belirlenmesi. GAP.1. Tarım Kongresi, 26-28 Mayıs, Cilt II, s: 893-900, Şanlıurfa, https://app. trdizin.gov.tr/makale/TmpRM09EazU/

Öktem, A. ve Öktem, A.G. (2006). Bazı Şeker Mısır (Zea mays saccharata Sturt) Genotiplerinin Harran Ovası Koşullarında Verim Karakteristiklerinin Belirlenmesi. Uludağ Üniv. Zir. Fak. Derg., (2006) 20(1): 33-46, http://acikerisim.uludag. edu.tr/bitstream/11452/3128/1/20_1_ 4.pdf

Panahi, M., Naseri, R. \& Soleimani, R. (2010). Efficiency of some sweet corn hybrids at two sowing dates in Central Iran. Middle-East Journal of Scientific Research, 6(1): 51-55.

Precheur, R.J., Doran, J., Schacht, D., Renk, C., Haddix, M. \& Davlin, J. (2006). Evaluation of sweet corn varieties at two grower locations in Ohio. Vegetable Research Reports, http://vegnet.osu.edu/ vegnet/index. html.

Sari, N. \& Abak, S. (1997). Effects of the low tunnel and sowing dates on the yield, plant growth and some agronomic characteristics of sweet corn (Zea mays L. var. saccharata). Turk. J.Agric.For., 21: 207-211.

Sencar, Ö., Gökmen, S. \& İdi, M. (1997). Effects of sowing date and growing methods on some characters in sweet corn. Turk. J. Agric. For., 21: 65-71, earsiv.gop.edu.tr

Sencar, Ö. Gökmen, S., Sakın, M.A. ve Ocakdan, M. (1999). Şeker mısırında (Zea mays saccharata Sturt.) koltuk almanın verim ve bazı özellik Türkiye 3. Tarla Bitkileri Kongresi, 15-18 Kasım, 1999, Cilt I, Genel ve Tahıllar, s: 456-461, Adana.
Sönmez, K., Alan, Ö., Kınacı, E., Kınacı, G., Kutlu, I.., Başçiftçi B.,Z. ve Evrenosoğlu, Y. (2013). Bazı Seker Mısırı Çesitlerinin (Zea mays saccharata Sturt) Bitki, Koçan ve Verim Özellikleri. Süleyman Demirel Üniversitesi Ziraat Fakültesi Dergisi, 8(1):28-40, 2013, ISSN 1304-9984, Arastırma Makalesi, https://dergipark. org.tr/en/pub/sduzfd/issue/29592/317 485

Tuık, (2020). https://biruni.tuik.gov.tr/ medas $/$ ?kn=92\&locale $=$ tr $\quad$ (access date: 8 Julay 2020).

Tuncay, Ö.M., Bozokalfa, K. ve Eşıyok, D. (2005). Ana Ürün ve İkinci Ürün Olarak Yetiştirilen Bazı Tatlı Mısır Çeşitlerinde Koçanın Agronomik ve Teknolojik Özelliklerinin Belirlenmesi. Ege Üniv. Ziraat Fak. Derg., 2005, 42(1):47-58, ISSN 1018-8851, https://dergipark.org.tr/en/download/a rticle-file/59143

Turgut, I. ve Balcı, A. (2001). Bursa Koşullarında Değişik Ekim Zamanlarının Şeker Mısırı (Zea mays saccharata Sturt.) Çeşitlerinin taze Koçan Verimi ile Verim Öğeleri Üzerine Etkileri. Türkiye 4, Tarla Bitkileri Kongresi, 17-21 Eylül 2001, Tekirdağ.

Turgut, I. Ve Balcı, A., (2002). Bursa Koşullarında Değişik Ekim Zamanlarının Şeker Mısırı (Zea mays saccharata Sturt.) Çeşitlerinin taze Koçan Verimi İle Verim Öğeleri Üzerine Etkileri. Ulud. Üniv. Zir. Fak. Derg., (2002), 16(2): 79-91, https://app.trdizin.gov.tr/

Ülger, A.C. and Becker, H.C. (1989). Influence of year and nitrogen treatment on the degree of heterosis in maize. Maydica, 34: 163-170.

Waligora, H. (1997). The influence of sowing terms on vegetation period and morphological characters of swet corn. Prace z Zakresu Nauk Rolniczych, 83: 135-140

(C) 2021 by the authors; licensee Journal of Applied Life Sciences and Environment, Iasi, Romania. This article is an open access article distributed under the terms and conditions of the Creative Commons Attribution License (http://creativecommons.org/licenses/by/4.0/). 